\title{
Web-Based Hiking Equipment Information System
}

\author{
Dian Rahadian ${ }^{1}$, Andri Suryadi ${ }^{2}$, Siti Husnul Bariyah ${ }^{3}$, Yuniar Purwanti ${ }^{4}$, Kuntum A N \\ Imania $^{5}$, Iman Nasrullah ${ }^{6}$. \\ \{dianrahadian@institutpendidikan.ac.id ${ }^{1}$, andrisuryadi@institutpendidikan.ac.id ${ }^{2}$, \\ sitihusnulbariyah@institutpendidikan.ac.id ${ }^{3}$ \} \\ Institut Pendidikan Indonesia Garut ${ }^{1}$
}

\begin{abstract}
Hiking Equipment Rental is a business in the field of services that rents camping equipment and equipment that requires an information system in the delivery of information, media promotion, data management, and loan transactions using barcodes. Therefore, a webbased hiking equipment and equipment rental information system is created to support the rental process. Making information systems starts from identifying system requirements, including making, data flow diagrams and entity relationship diagrams. After that planning the website application using XAMPP software, database, HTML, CSS, notepad ++, web browser. The results of making a website information system rental camping equipment there are several views and menus that can be used by consumers to get news and information about what items can be borrowed on certain days.
\end{abstract}

Keywords: Hiking tool rentals, information systems, barcodes.

\section{Introduction}

This research has a background by the result of temporary observation in the Indonesia educational institute[1], where many students who like hiking and has limited hobbies with supporting facilities must be owned by these climbers, such as carriers, tents, sleeping bags, etc. [2]

The difficulties of finding hiking equipment rental service because of the rather expensive price that made climbers must find other ways to get the facility. One of them is by renting.[3]

Hiking Equipment Rental is a service business in rental equipment and camping equipment that uses a web-based information system [4]. By using a business information system, hiking equipment rental services that offer various purposes such as carriers, tents, sleeping bags, portable stoves, and others[5]. 


\section{Method}

In the construction of a web-based hiking equipment rental information system, there are 4 stages of the waterfall that are passed through analysis, design, coding, and testing [6]. The system development method with the waterfall model can be seen in Figure 1.

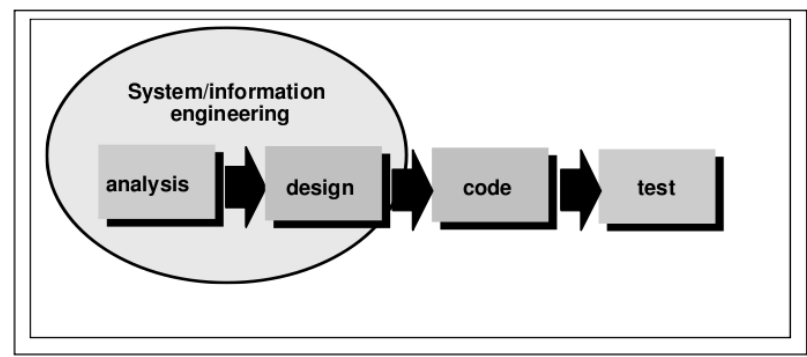

Figure 1. Waterfall Model (Pressman, 2001)

\subsection{Analysis}

Stages of analysis are carried out analyzing ongoing business processes and exploring the functional requirements of the system to be built [7], [8]. Modeling business processes is done using BPMN assistance and the functional requirements of the system are illustrated by UML diagrams. Data needed in this stage is obtained through 3 methods, namely:

a) Observation

Observation is done by observing the flow of the web-based hiking equipment rental system.

b) Interview

The interview aims to get more detailed and definite information about the research conducted.

c) Document Analysis

Document analysis is done by collecting and studying document documents related to webbased hiking equipment rental systems.

\subsection{Design}

At this stage, the application architecture design, data design, and system user interface are carried out. The design is carried out based on the functional needs that have been explored [9]Designing UML diagrams consisting of software design with a Use case, Context Diagram, Data Flow Diagram, Entity Relationship Diagram, application architecture, and designing user interfaces for web applications. [10] 


\subsection{Code}

This stage is the stage to implement the design that was made in the previous stage. This stage is to realize the design that was successfully made into the program code.

\subsection{Test}

Testing is done using black box testing. Testing using this black box ensures that the system is built according to predetermined needs and is ready for use.

\section{Research Result}

The following are the results of the research stages starting from the analysis stage, design stage, coding stage and testing phase

\subsection{Analysis Phase}

Based on the results of the analysis that has been carried out that the media/tools needed for managing the administration of hiking equipment rentals.

\subsection{Design Phase}

At this stage, the design model of the User Experience Design and User Interface Design are carried out. User Experience Design is an application design about how interactions on applications can run[11]. User Experience design uses use case diagrams, activity diagrams, and sequence diagrams. The use case diagram is presented in the following picture: 


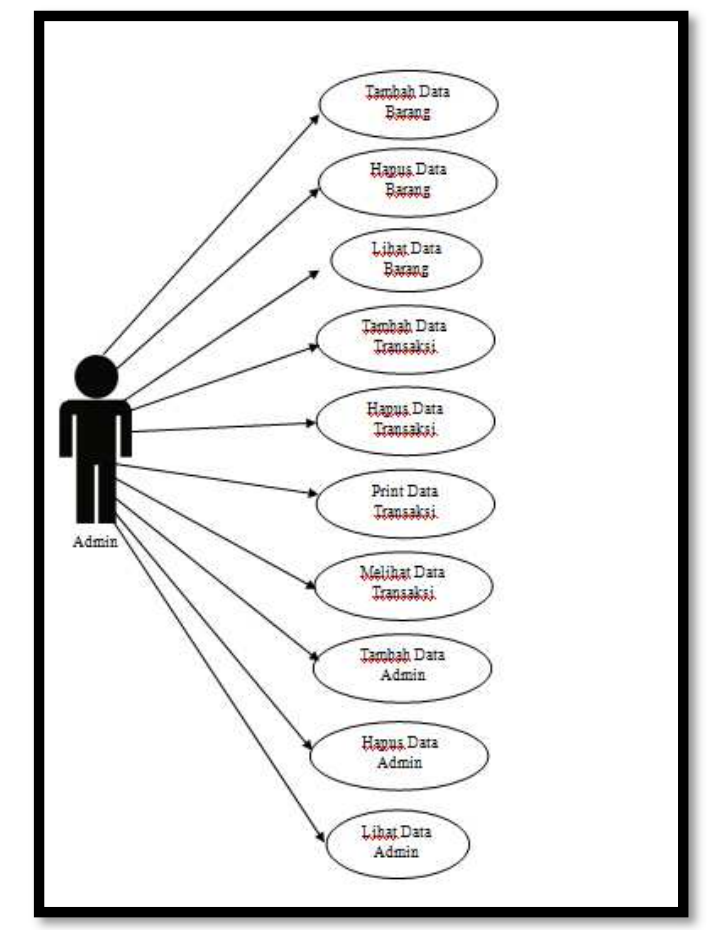

Figure 2. Use Case for Rent of Web-Based Hiking Tools

the diagram illustrates how the system reaches its goal. Activity is a process that is being modeled. The following is the implementation of activity diagrams in the Web-Based Hiking Equipment Rental Service Information System. Activity diagram consists of adding item data, deleting item data, see item data, adding transaction data, deleting transaction data, printing transaction data, viewing transaction data, adding admin data, deleting admin data and viewing admin data [12]. 


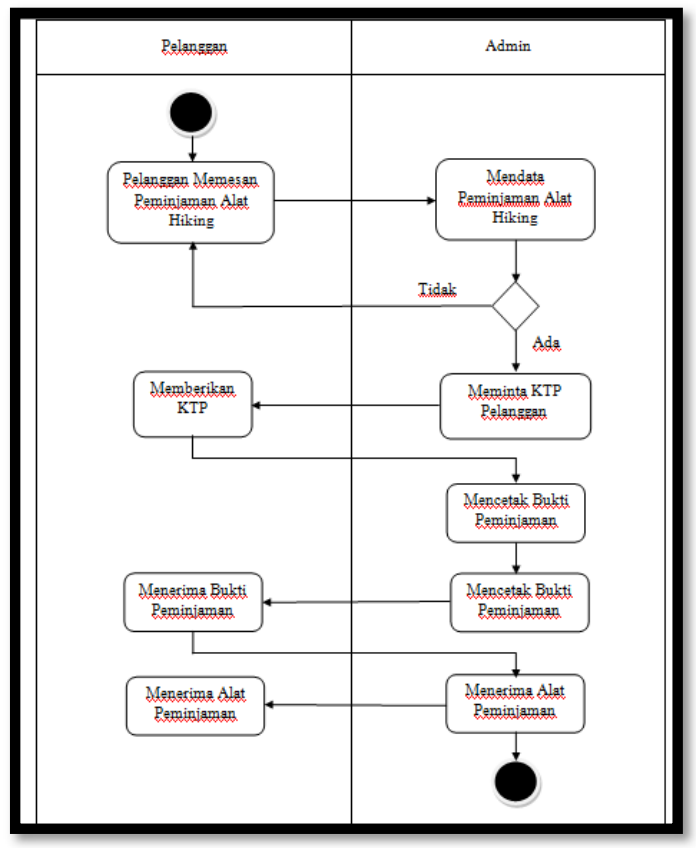

Figure 3. Activity Diagram Renting a Hiking Tool

In Figure 3 the Activity Diagram Renting a Hiking Tool where customers will rent a hiking tool will then interact directly with the admin. 


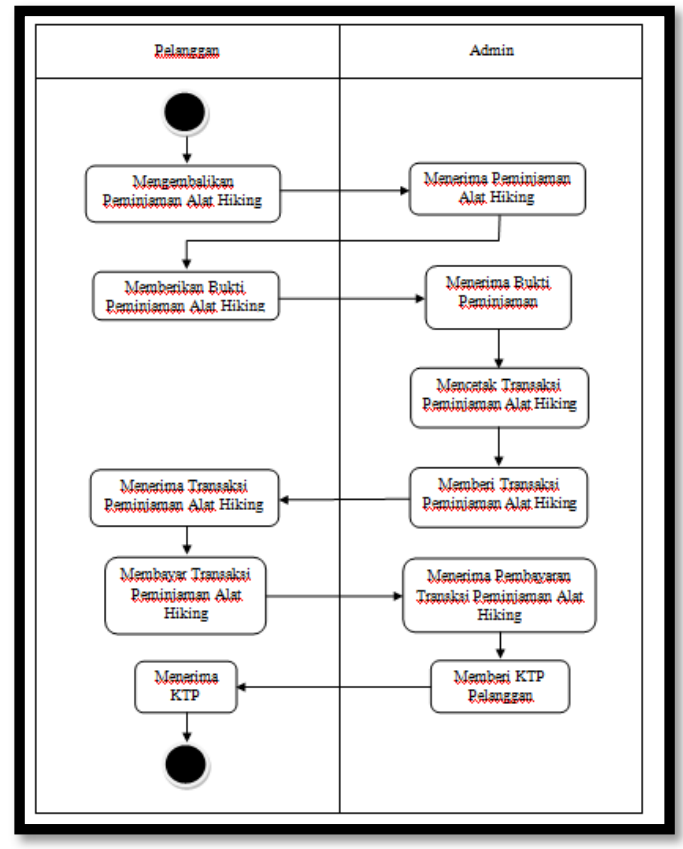

Figure 4. Activity Diagram of Hiking Tools

Figure 4 is a return diagram for hiking tools where the customer will return the hiking tool and interact with the admin.

Entity Relationship Diagram (ERD) is a technique used to model data requirements of an organization, usually by System Analyst in the requirements analysis phase of a system development project. Next is ERD Loan Hiking Tools in Figure 5:

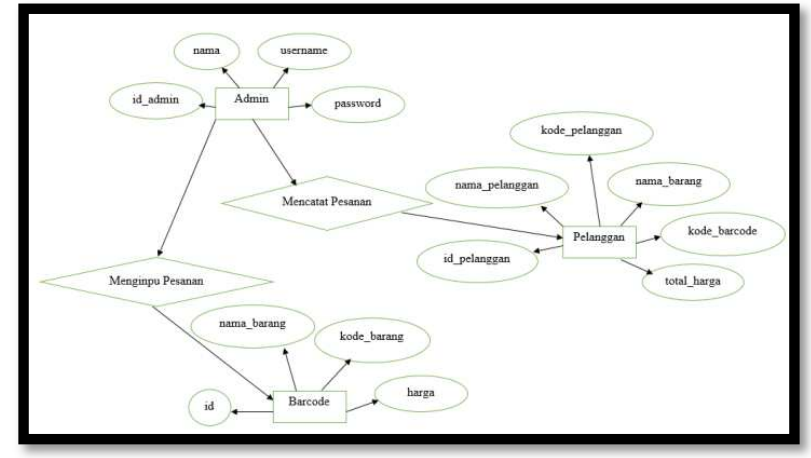

Figure 5. ERD Web-based Hiking Equipment Rental 


\subsection{Implementation Stages/Coding}

At this stage, it will implement the results of the design in the previous step. The following are the results of the implementation of the code that has been done.

a. Display Login

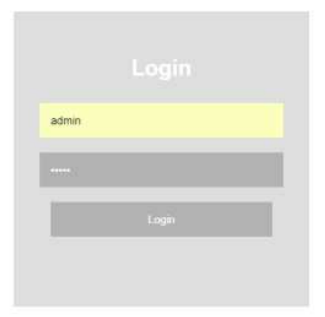

Figure 6. Display Login

Figure 6 is the initial appearance of the implementation. This login display will be used by the admin as the initial stage of using the web application.

b. Home View

The Web-Hiking Information System design to enhance the active role of Customers in the transaction process consists of several activities [1].

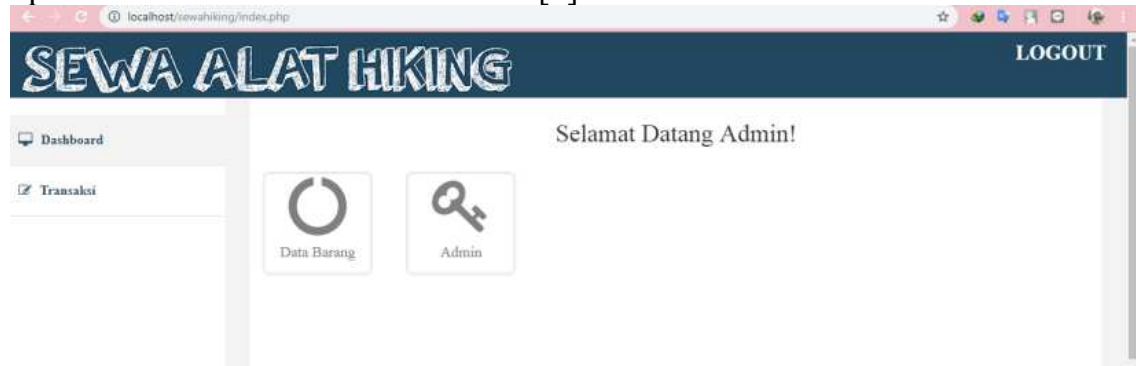

Figure 7. Display of the Home

In figure 7 the display of the homepage is a display after the admin has successfully logged in. The home screen consists of a dashboard and transactions. 
c. Display of Hiking Equipment Data

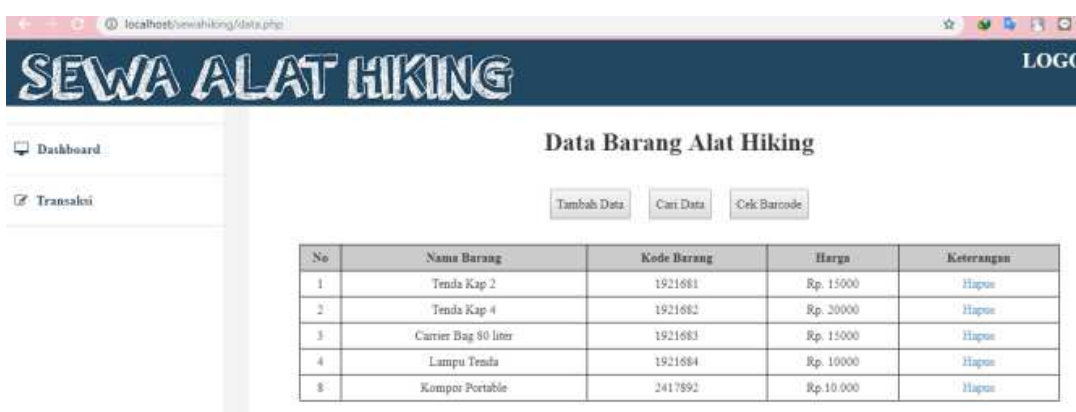

Figure 8. Display of Hiking Equipment Data

Figure 8 is a data display of hiking gear items. This item data display can do several features including adding data and checking the code.

d. Display of Results Check Barcode of Goods Data

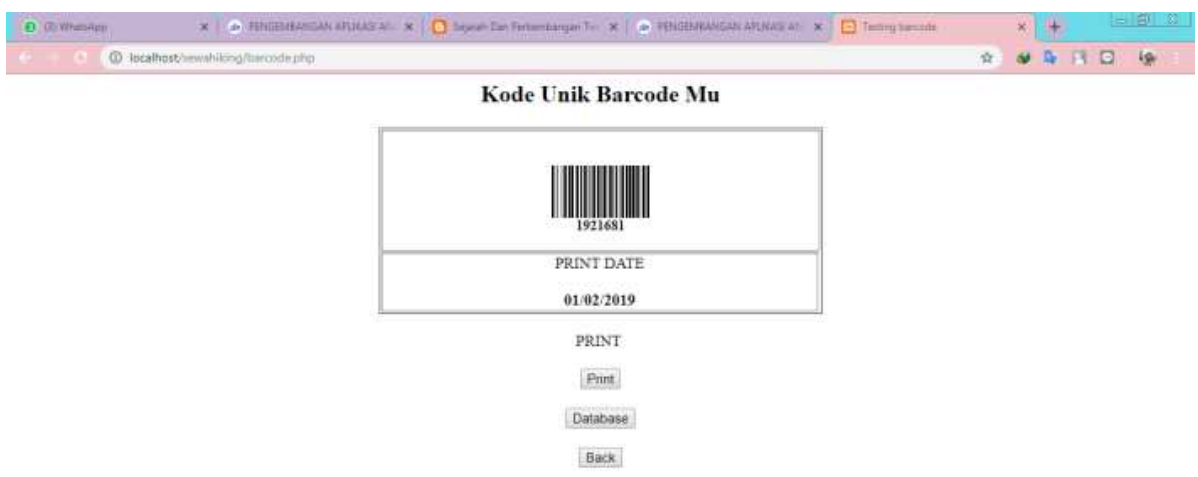

Figure 9. Display of barcodes for goods. 
In Figure 9 this is a barcode display that will be affixed to hiking gear items. This barcode can be printed directly using the application. With this barcode can facilitate transactions that occur in the rental of hiking equipment[13].

e. Display of Transaction Data

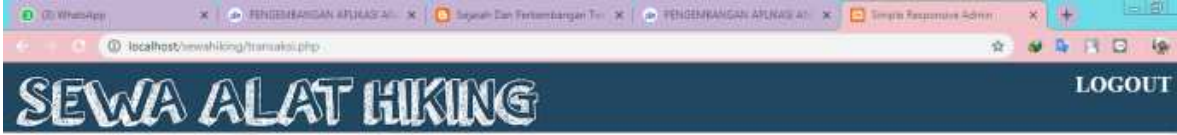

Daslboard

Data Transaksi Alat Hiking

Q Trasuaks

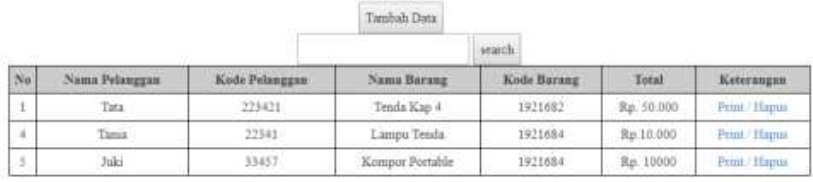

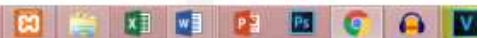

Figure 10. Display of hiking equipment transactions

In figure 10. This is a display of transaction data hiking tools after a transaction using a barcode.

f. Display Add Transaction Data
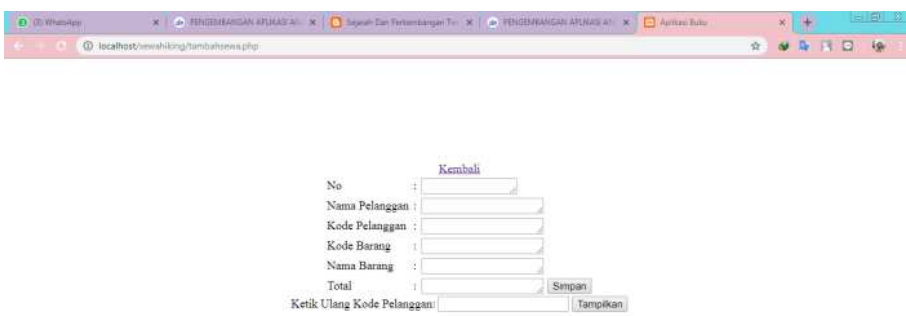

Figure 11. Display Add transaction data 
Figure 11 is a view of adding transaction data. In adding transaction data there is an item code that can be entered in barcode data[14].

\subsection{Testing Stages}

This stage is the stage of testing the application after the implementation phase has been completed. The following are the results of testing using blackbox:

Table 1. Blackbox Testing

\begin{tabular}{|c|c|c|}
\hline No & Tested features & Information \\
\hline 1 & Login & Succeeded \\
\hline 2 & Data Display & Succeeded \\
\hline 3 & Add Data & Succeeded \\
\hline 4 & Edit Data & Succeeded \\
\hline 5 & Delete Data & Succeeded \\
\hline 6 & Transaction & Succeeded \\
\hline
\end{tabular}

\section{Conclusion}

Web base hiking equipment information system can help the process equipment more easy with uses the internet connection so the high access. It makes easy to add the product that will rent because it is put in the database. Base on tested blackbox told that the function of web base equipment information system success all. 


\section{References}

[1] Y. P. and K. I. D Rahadian, S H Bariyah, I Nasrullah, "Development of online learning Design," J. Phys. Conf. Ser., vol. 1402, no. 6, 2019.

[2] A. Kadir, "Pengenalan Sistem Informasi," 2003.

[3] and M. R. J. Subeki, Beki, “Aplikasi Info Halal Menggunakan Barcode Scanner Untuk Smartphone Android," J. Inform. 3.1, 2016.

[4] A. F. Harry D, Lukman, "Perencanaan Sistem Informasi Jasa Pengiriman Barang berbasis Web," 2016.

[5] R. Fahrudin, "Sistem Informasi Penyewaan Alat Outdoor Di Warger Camping Equipmen," J. Progr. Stud. Sist. Informasi, Univ. Komput. Indones., 2014.

[6] A. Suryadi, "PERANCANGAN APLIKASI GAME EDUKASI MENGGUNAKAN MODEL WATERFALL," J. PETIK 3.1, 2017.

[7] T. Sutabri, Analisa Sistem Informasi. Yogyakarta: Andi, 2004.

[8] K. Kendal, Analisis dan Perancangan Sistem: Edisi ke lima-jilid 1. Jakarta, 2007.

[9] R. R. O. Dian Rahadian, Gina Rahayu, "Teknologi Pendidikan: Kajian Aplikasi Ruangguru Berdasarkan Prinsip dan Paradigma Interaksi Manusia dan Komputer," J. PETIK, vol. 5, no. 1, pp. 11-24, 2019.

[10] M. F. Alghina, "Perancangan aplikasi penyewaan alat outdoor berbasis android (studi kasus cemara adventure rental outdoor)," 2017.

[11] S. Sudarmaji, "Migrasi dan Optimalisasi Database Sistem Informasi berbasis E-Learning Program Diploma III Manajemen Informatika Universitas Muhammadiyah Metro," MIKROTIK J. Manaj. Inform. $6.2,2017$.

[12] S. M. Y Purwanti, KAN Imania, D Rahadian, SH Bariah, "Mobile learning in promoting student's engagement," J. Phys. Conf. Ser., vol. 1402, no. 6, p. 066033, 2019.

[13] D. C. G. Simanjuntak, “Analisis Perancangan Sistem Barcode dalam Menangani Aliran Raw Material Kayu pada Departemen Lumberyard di PT Ebako Nusantara Semarang," Ind. Eng. Online J. 4.4, 2015.

[14] D. D. Siti Husnul Bariah, Dian Rahadian, "SMART CONTENT LEARNING DENGAN MENGGUNAKAN METODE BIG DATA ANALYSIS PADA MATA KULIAH MEDIA PEMBELAJARAN ILMU KOMPUTER,” J. Teknol. PEMBELAJARAN, vol. 2, no. 1, 2017. 